\section{THE GERMAN MUSEUM OF SCIENCE AND} TECHNOLOGY.

THE guide ${ }^{1}$ to the collections in the new German 1 Museum at Munich shows that the examples of the Conservatoire des Arts et Métiers in Paris, and of the Machinery and Inventions Museum at South Kensington, have been successfully followed, and even improved upon, in the Bavarian capital. In the old National Museum in the Maximilianstrasse a remarkable collection of "Meisterwerken " of science and technology has been brought together in a few months, a collection which is well wor thy to rank with those which are the results in Paris of a hundred years, and at South Kensington of fifty years, of strenuous work.

In Germany the scheme for such a museum was suggested on May 3, 1903, by Oscar von Miller. The idea was adopted with enthusiasm; and George Krauss, the eminent authority on the locomotive, was the first to show practical interest in the scheme by presenting the sum of $5000 l$. A site for the museum was granted by the municipality of Munich, and a temporary home was found in the old National Museum and in the Isar barracks. The aim of the museum is to illustrate the gradual historical development of scientific research and of technology by means of original apparatus and machines, and by means of a library of ancient and modern works. On September 20, 1906, thirty-one competitive designs for the new museum were received from German architects, and on October 20 the first prize was awarded to Gabriel von Seidl for his design for a building, the cost of which was estimated at $375,000 l$. For meeting this cost, the city of Munich voted 50,oool., the Bavarian Government Ioo,oool., and the German Imperial Government roo,oool. The greater part of the remainder has been subscribed by scientific and technical corporations and individuals. On November I3, the day of the opening of the temporary museum, the foundation-stone of the new building was laid by the

Prince Regent of Bavaria in the presence of the German Emperor, and in a few years' time the collections will have a stately permanent home.

In the meantime the collections are admirably displayed in the temporary museum, and a mere enumeration of the classification of the contents of the fifty-six rooms will suffice to show the vast field covered. The classification (Fig. I) is as follows :-I, geology ; 2, mining; $3^{-6}$, metallurgy ; 7 , hydraulic n!otors; 8-9, steam engines; 10, land transport; $1 \mathrm{I}-12$, roads; $\mathrm{I}_{3}-\mathrm{I} 4$, motors; $\mathrm{I}_{5}$, astronomy; $\mathrm{I} 6$, geodesy; 17 , mathematics; 18 , mechanics; 19-20, optics; 21 , heat; $22-23$, acoustics; $24-26$, electricity; 27. telegraphy; 28, telephony; 29, drawing and painting; 30 , writing and printing; $3 \mathrm{I}$, photography; 32. horology; $33-35$, textile industries; $36-37$, agriculture; 38 , dairy work; 39 , brewing and distilling; $40-45$, chemistry; 46 , hydraulic engineering; $4 \pi$,

1 "Deutsches Museum von Meisterwerken der Naturwissenschaft und Technik." Führer durch die Sammlungen. Pp. 158 ; with 55 illustrations. (Leipzig: B. G. Teubner, rgos.) Prire $r s$.

$$
\text { Nó. } 2029 \text {, vol. } 78 j
$$

inland navigation; 48, canals; 49-5I, naval architecture; $53^{-55}$, library and plan collection; and 56 , court of honour.

It is impossible in the space available even to enumerate the many objects of interest shown. Walking through the rooms in the order indicated, one notices the first geological map of Bavaria by Michel in I768, Siemens's first electric mine locomotive (I88I), a model showing the Ilgner system of electric winding in shafts (Fig. 2); a huge model, on a scale of one-twelfth the natural size, of Krupp's steelworks, with the 50-ton steam hammer, and near it an original village smithy of the nineteenth century, and the first cast-steel bell made by Jacob Mayer in 1854. Among the hydraulic motors there are an old Roumanian water-wheel, such as that described by Leonardo da Vinci, the prototype of the modern turbine; the first Fourneyron turbine; and the Reichenbach hydraulic engine, built in $18 \mathrm{r} 7$, and used until 1904 for pumping brine from Berchtesgaden. 
of the apparatus of Otto von Guericke, Galileo and Volta. Passing on to the technological group, one notices the original lithographic press invented by Senefelder in 1797 , and reproductions of Hargreaves's

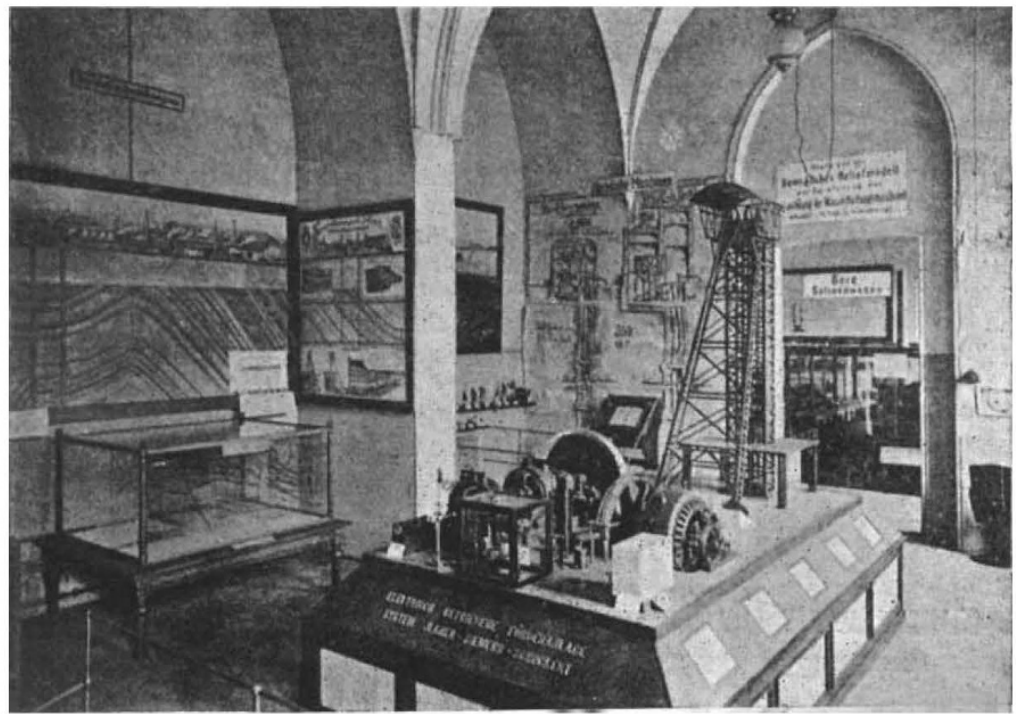

F1G. 2.-Model of electric winding plant.

spinning jenny and of the first Jacquard loom. The chemical section is of special interest. There are four completely equipped laboratories of different epochsan alchemist's laboratory (Fig. 3), with portraits of Albertus Magnus, Paracelsus, Agricola, Van Helmont and other investigators of the sixteenth and seventeenth centuries; an eighteenth-century laboratory; Liebig's laboratory as installed at Giessen in 1839; and, lastly, a modern laboratory illustrating the latest developments of chemical apparatus.

The Court of Honour contains portraits in oils of Josef von Fraunhofer $(1787-1826)$, K. F. Gauss (1777-1855), G. W. Leibniz (16461716), Otto von Guericke (1602-86), and Justus von Liebig (1803-75); and busts of Werner von Siemens (1816-92), Alfred Krupp (1812-87), Robert Mayer (I8I4-78), Hermann von Helmholtz (1821-94), Robert Bunsen $(1811-99)$, and Henne Gensfleisch, known as Gutenberg (died 1468). There is also a collection of medals of scientific interest, including the Bessemer Gold Medal of the Iron and Steel Institute, and other medals awarded by British societies. Framed on the walls is a collection of historical documents, letters of Ampère, Berzelius, Faraday, Ohm and others. There is also a volume recording in chronological order the gifts received by the museum from all parts of the world.

The museum is keenly appreciated. The number of visitors averages 3000 on Sundays and Iooo on week-days. The detailed information given on the labels describing the objects has been compiled with scrupulous care. and adds greatly to the educational value of the collections. Huxley's definition of a NO. 2029, VOL. 78] museum was that it is a consultative library of objects. The German Museum is a consultative library for the engineer and the man of science, and it is something more. It is an effective agency for the enlightenment and education of the masses.

Bennett H. Brovgh.

\section{THE NORTH-WEST PASSAGE.}

STRICTLY speaking, the north. west passage was accomplished in 1847 , when Franklin and his men, retreating from their abandoned ships to the north-west of King William Land, passed through Simpson Strait to the mouth of the Great Fish River and so crossed the tracks of Dease and Simpson, who in 1839 had reached Castor and Pollux Bay from the west. The existence $\mathrm{cl}$ channels at least continuous, and possibly navigable, from east to west was thus proved. Later, in 1853, McClure and his men, abandoning the Investigator in Mercy Bay, Banks Land, which point she had reached from the Pacific, retreated to the ships of Belcher's squadron, then wintering on the south-east of Melville Island, and ultimately reached home. This was the first party to complete the traverse of the American Arctic regions from ocean to ocean. Technically, McClure did the northwest passage, but he proved at the same time that his route was quite impracticable. The Enterprise under Collinson, the Investigator's companion ship, did more towards the discovery of the passage by reaching. Cambridge Bay from the

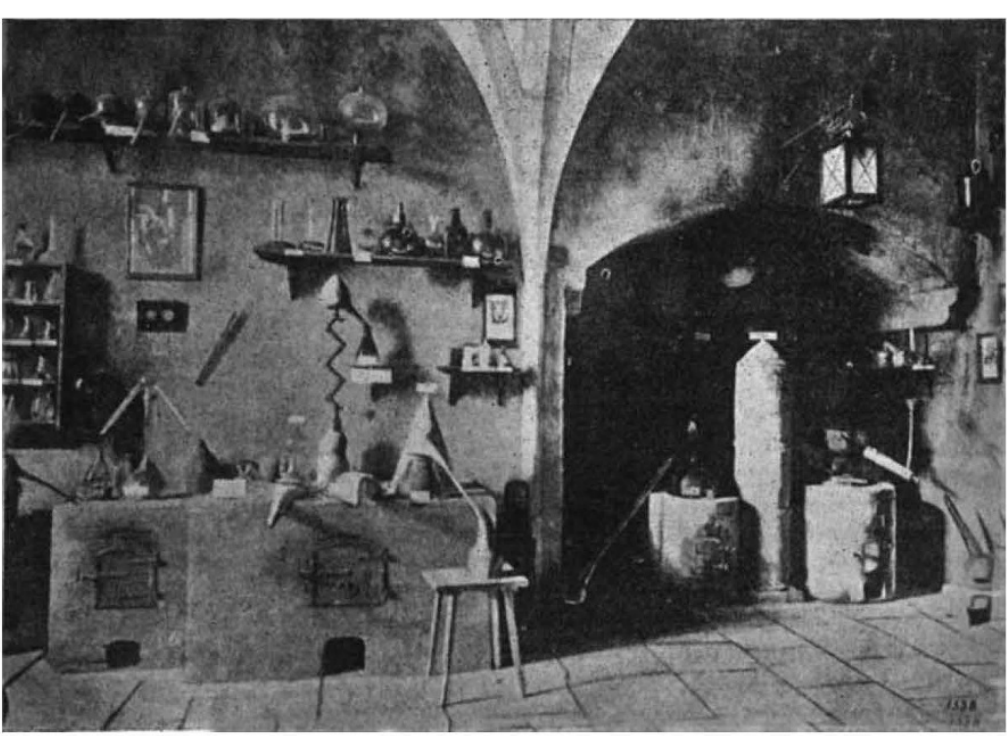

FrG. 3-An alchemist's laboratory of the sixteenth century.

west. Consequently, the only part untraversed by a ship was from the north of King William Land to 1 "The North-West Passage." Being a Record of a Voyage of Exploration of the Ship Gjöa, 1903-7. By Roald Amundsen; with a Supplement by Lieut. Hansen. 2 vols. Pp. xiii +335 and pp. ix +397 ; illustrated. 